\title{
Free Movement of People, Goods, Services, and Capital in the Context of the Balkan Stability Pact
}

\author{
Mladen Stanicic ${ }^{1}$
}

The Balkan Stability Pact is a strategic concept whose aim is to foster long-term peace and stability in South Eastern Europe. It is becoming an indispensable element of the global security structure that is currently being constructed in relations between the large powers - the U.S., Russia, and China - with the active participation of the United Nations, the European Union, international financial institutions, and individual countries. As one of the sponsors of the Pact, the European Union is keenly interested in stability and peace among its next-door neighbors, some of whom are covered by the pending Eastern enlargement of the EU. This enlargement is intended to transcend centuries of civilizational and religious division in Europe, which have been the causes of many political and armed conflicts in the past. The vision of Europe in the twenty-first century, reaching all the way to the borders of the former Soviet Union, is that of a multicultural community encompassing states with diverse religious, ethnic, and cultural characteristics.

The EU as an instrument of international integration is one of the most important elements in the process of globalization, which is in turn based on structural changes in the world economy. The theory of liberal internationalism views international integration as an inseparable aspect of globalization and a basic foundation for the realization of the concept of "peace by integration" in an international system characterized by increasing interdependence, economic and otherwise. ${ }^{2}$ Under the conditions of globalization, international integration is organized with the purpose of contributing to better control and coordination of international economic and political relations, and of improving nations' internal political and economic organization. Thus integration is nurtured by the process of continuing economic growth, carried out through the intensification of economic exchange, trans-border differentiation of the division of labor, the merging of smaller segmented markets into a common market, and economic and monetary union. These theoretical precepts, which have so far been proven effective in many cases, prove that participation in international integration, as an inseparable part of the globalization process, is far more favorable, economically and politically, for each of the members than remaining outside the integration process. Since the economic and political benefits from participation in this integration are interactive, it follows that the essence of international relations as a whole is developed within and

\footnotetext{
${ }^{1}$ Dr. Mladen Stanicic is Director of the Institute for International Relations in Zagreb, Croatia.

${ }^{2}$ Reinhard Meyers, Temeljni pojmovi $i$ teorijske perspektive meðunarodnih odnosa (OsijekZagreb-Split: Pan-Liber, 1999).
} 


\section{THE QUARTERLY JOURNAL}

among the participants in international integration. The position of one country within an institution of international integration determines its position in international relations; thus, the main content of a country's international relations proceeds from its participation in international integration. It is particularly relevant to small countries, like those in South Eastern Europe (SEE).

The European Union was established upon the precepts of liberal internationalism, both internally and externally. Liberal internationalism in international relations is compatible with the value systems of each member state, which are based upon liberal democracy and the rule of law through a constitution. Since participation requires the presence of a compatible value system both internally and externally, this becomes the basis for the democratization of international relations, which by the nature of things enables small states as well as big ones to actively and equally participate in international relations, according to their ability and competence to adjust to this value system. Therefore, participation in international integration is the best way towards the realization of these states' national interests under the conditions of globalization. This goes for SEE countries as well.

One of the most significant characteristics of liberal internationalism, particularly implicated in the European integration process, is the implementation of the "four freedoms": free movement of persons, i.e., of the labor force; of goods; of services; and of capital. These freedoms are the foundation of the EU, functioning since its very beginning with its first six members in 1957 up to the present day, and the process of its future Eastern enlargement, as well as the Stability Pact process, will also be based upon them. They are prerequisites for the successful functioning of the integration process on:

- The political level, because they help define the compatibility of each member state's value system, which in the case of the EU is based upon liberal democracy and respect for the rule of law at the internal level and on liberal internationalism on the international level;

- The economic level, because they allow for a gradual convergence of economic development among all member states, without which an economic and monetary union cannot function successfully;

- The cultural level, because they are the basis for mutual understanding and respect, which are basic components of every voluntary integration process;

- The scientific and technological level, because they are critical to the gradual convergence in development, which is especially important in relation to the conditions of globalization. 


\section{The Specific Position of the SEE Sub-region}

Each country or group of countries that wants to become an equal member of the EU-which is at the moment the most prominent and concrete embodiment of the process of international integration - has to be aware of the fact that the implementation of these four freedoms must be indivisible, not only for the current member states, but also for any country that will become an equal member state in the future. This is applicable both to the SEE countries, the majority of which are in various phases of the process of stabilization and association to the EU (through the SAA and Stability Pact process), and to the other countries in the region that are in more advanced stages of integration-Bulgaria and Romania on the one side, and Hungary and Slovenia on the other. The four freedoms cannot be evaluated based on some institutionalized phases of cooperation; that is, they cannot be measured one way in the countries that are institutionally closer to full integration (Hungary, Slovenia, Bulgaria, and Romania), and in a different way in the countries that are somewhat further away from full integration. Even the countries that are in different stages within the framework of the SAA and Stability Pact process cannot be viewed separately. ${ }^{3}$ The phases of functional and neo-functional integration in their very nature cannot be restricted within the frameworks of different institutional phases of association, because this would be contradictory to the very philosophy of the four freedoms. The perfect example for this is the process of the Stability Pact, from the very beginning of its activities.

What should be taken into account, however, are the specific characteristics of particular sub-regions, which should gradually become an institutional part of the wider region, i.e., the EU. ${ }^{4} \mathrm{~A}$ significant dose of fine-tuning is necessary here, particularly in the light of the fact that EU enlargement has several times thus far been based on the regional principle. For instance, Great Britain and Ireland were accepted together, as was the case with Spain and Portugal. It has not been proclaimed as a formal principle anywhere; thus, for instance, Denmark was accepted together with Great Britain and Ireland. However, wherever it is possible the EU applies the regional principle, for the very sake of pragmatism, because it does not want to accept as members countries that have unresolved problems with their neighbors. This would mean that those problems would be carried over to the Union, which would have an unfavorable impact on the cohesion of the whole. The EU is also applying that principle in the first phase of its Eastern enlargement, thus motivating the Central European countries to increase their economic cooperation by establishing the free trade area CEFTA (Central European Free Trade

\footnotetext{
${ }^{3}$ Out of five countries participating in that process, Croatia has signed the SAA, Macedonia has only ratified it, while Albania, Bosnia and Herzegovina, and FR Yugoslavia have not yet started to negotiate. Among other countries of the region, Hungary and Slovenia are in the lead for entrance to full membership, while Bulgaria and Romania are in the second group of candidates, but are still closer to full integration than the countries of the SAA process.

${ }^{4}$ For the sake of this paper, SEE will be considered as a sub-region and the EU as a region.
} 
Area) that encompasses all countries from the first two groups of candidates for accession to full EU membership ${ }^{5}$.

That is why the example of CEFTA as a successful sub-regional integration body is often cited in Brussels, and it should be looked to by the SEE countries as well, particularly by the members of the Stability Pact process. The inappropriateness and the unrealistic quality of such automatic comparisons is actually one of the themes the Union should clear up so that it can complete the final stage of its Eastern enlargement (with the countries of the SAA process) as successfully as possible.

The area of the Stability Pact in South Eastern Europe is today composed of nine or ten states (the uncertainty being due to the joint status of Yugoslavia and Montenegro). It is certainly a significant area, if not because of its economic development, then at least according to the number of inhabitants. It encompasses developed countries, middle-developed countries, as well as the three poorest European countries (Macedonia, Albania, Bosnia-Herzegovina). There is one NATO member in the group (Hungary), two presumable candidates for the next round of NATO enlargement (Slovenia and Romania), two states that have started negotiations on their entrance to the EU (Hungary and Slovenia), two states that have signed the Association Agreement (Romania and Bulgaria), and five countries that are members of the Stabilization and Association Agreement. This market, starting with the goal of faster economic development, could also open the way for greater political co-operation with the aim of a joint resolution of some regional problems, also within the mechanism of the Stability Pact.

However, while doing so, some specific qualities should be taken into account that are particularly related to the historical development of all countries in the region. First, this sub-region is one of those areas where a regional integrative body that would attract other countries has never been built, nor have any forms of cooperation based upon some other common interest been established. Without any visible common interest, it is precisely the dark pages of sub-regional history that become more important. Economic analyses, on the one hand, speak about the potential possibilities of cooperation. On the other hand, numerous reservations are instantly brought up which stress that each of these states has always been directed toward relations outside the region, that no workable arrangements have ever been made between those states and, finally, that there is a constant fear that linking a state's future to the destiny of the sub-region, whose geographical name- "the Balkans"- has a pejorative meaning for many states in the area, would make the road to European integration more difficult. With so much bad historical experience, and so many fears in the present, it is very hard to develop any level of

\footnotetext{
${ }^{5}$ Within the framework of the first group of candidates are the CEFTA members - the Czech Republic, Hungary, Poland, and Slovenia - and within the framework of the second group are Bulgaria, Romania, and Slovakia. Along with those countries, Estonia is a member of the first group, while Latvia and Lithuania are members of the second.
} 
sub-regional cooperation, which must be the first step in proving the maturity and capability of these states to move toward the resolution of their problems and in the process discover some useful forms of unity.

The wars in former Yugoslavia made these differences and hostilities even worse. Even arguments that could have been used as a motive for greater cooperation and unity took on a negative connotation during the war, pulling the entire process of development as well as the regional mind-set backwards. Of course, today it is a significant aggravating factor that makes it difficult to build new European relations, to say nothing of the application of the theory and practice of the four freedoms. The sensitivity of the countries that have passed through the devastation of war should be taken into consideration. The belief that a vision of future material benefit could neutralize this bitter inheritance is surely naïve and does not correspond to reality. The attempt to push all the states in the region together without the resolution of some basic issues, rendering the aggressors and victims equal, is a typical example of a mechanical, bureaucratic approach, but is not a foundation on which cooperation that would be desirable and useful to all can be developed.

A bureaucratic approach that, for the sake of higher political reasons or lower human ambitions, would seek quick solutions, acting as a supervisor or the mere initiator of action, cannot succeed here either. A mechanism of bureaucratic decision-making from the international community has recorded a sufficient number of failed examples in the region over the past several years that should be carefully analyzed in order to prevent their repetition in the first phase of Eastern enlargement of the EU. No matter how poor or devastated by war these countries are, the majority of them are not yet ready, at least for the time being, to unconditionally accept supranational mechanisms that would significantly weaken their sovereignty. Strong outside pressures to create and offer some alternative solutions that would be closer to the bureaucratic centers of decision-making have not so far been welcomed by citizens in the region who, in the quite recent past, chose the national option in spite of the fact that perhaps it was less useful for them. Only projects that take into consideration the reality of intra-regional relations, the mood of the main protagonists, and the possibility of their gradual realization can hope to become the basis for successful development and eventually the foundation for cooperation based on the philosophy of the four freedoms. ${ }^{6}$

\section{Security Aspects of the Process}

Gradual accession to the EU is a project of the kind that, after many failed attempts at joint projects in the past, can motivate the countries of the sub-region to closer cooperation. After their difficult historical legacy, during which these

\footnotetext{
${ }^{6}$ For further information see Radovan Vukadinovic, Security in the southeast of Europe [Sigurnost na jugoistoku Europe] (Zagreb: HUMS, 1999).
} 
countries had completely different geo-strategic goals, this is the first common goal that all want to achieve. Therefore, the EU should make the possibility clear to those countries, i.e., should offer them credibly a joint prospect of entrance into the Union, regardless of the various institutional phases of that process. For political leaders in the region-and, what is more important, for the people at large-Europe is a system without an alternative, and the vast majority of citizens are aware that it is the future for this area. Therefore, only if the process of integration is consistently and credibly implemented, and if every project set up in the region relates to wider regional European solutions, can a sincere and concrete level of sub-regional cooperation be established that will implement the philosophy of the four freedoms. That is why the Stability Pact should not, by any means, be a substitute for either the Eastern enlargement of the EU or for the SAA process. Those processes must be complementary.

One should also pay a lot of attention to the security aspects of this process, which are very much bound up with the forms of cooperation included under the rubric of the four freedoms. The events following the collapse of former Yugoslavia showed that instability in the sub-region threatens broader regional and global security. The UN and NATO's peace-keeping actions, as well as NATO's armed action, helped to pacify parts of this region by force, establishing a kind of protectorate over the most sensitive focal points: a full protectorate in Kosovo and a modified protectorate in Bosnia-Herzegovina. There are many indications that the international presence might be required for as long as it takes to complete the process of the EU's Eastern enlargement. It is increasingly evident that this process is compatible, in the sense of security, with the doctrine of military-political containment. The "Europe of the thirty" assumes a broader European region of peace, stability, and prosperity on the basis of long-term strategies that will enable the EU to more than double the number of its members, from the present-day fifteen to over thirty members. With its accelerated Eastern enlargement, the EU will also expand the limits of broader regional security. This proves again that the process of Eastern enlargement should not be limited to admitting the first and the second group of candidates, currently the twelve countries with whom accession agreements have already been signed. We should add also that this includes the countries that have already signed or will soon sign the Stabilization and Association Agreements, which means the states of South Eastern Europe.

The events in this region over the past ten years have highlighted some other characteristics of international relations, which should also be considered. The political experience of this part of the world clearly shows that the main agent of change is the United States and its policy. The United States was the decisive factor in stopping the wars and establishing peace in Croatia, Bosnia-Herzegovina, and Kosovo. Seen from a broader perspective, the geo-strategic space of South Eastern Europe can be linked with the turbulent parts of the neighborhood. Quite obviously, it is in the United States' interest to maintain this sub-region as a sta- 
ble and peaceful environment, particularly during and after the anti-terrorist campaign in Central Asia, which is in fact in the near vicinity of SEE. Bosnian-type conflicts-instability either in Kosovo or in Macedonia - would fit poorly with American interests and objectives. Having South Eastern Europe as a link with Western Europe and as a peaceful hinterland of the European continent is the desired state of affairs. The U.S. activities in Macedonia and Kosovo clearly reflect this line of thinking. In this context, sub-regional linkages in South Eastern Europe gain further relevance. A rational adoption of a functional, sub-regional co-operation regime and of projects that are being offered under this scheme are at the moment in the national interest of all countries concerned. But, for the time being, all that can be achieved only if the foreign troops remain in the area as long as is necessary.

\section{The Relevance of Functional Cooperation}

Functionalism as one of the theories of integration starts from the assumption that the development of international integration should be based on functional connections, through various common activities such as health care, science, culture, trade, economy, transport, etc. Successful cooperation on a functional basis without the establishment of a political body or another supranational authority (in the long term) leads to mutual understanding and creates the basis for an easier solution of political problems. The experience of the establishment of the EC for coal and steel led some of its theoreticians to comprehend the value of functional cooperation and integration, primarily when the subject is cooperation and connection on a regional (or sub-regional) level, instead of on the global level. Neo-functionalism, as a continuity of functionalism, considers exactly such doubts regarding the functioning of integration that point to the need for the establishment of supranational systems or the possibility of development through some form of intergovernmental cooperation. As distinguished from functionalism, theoreticians of neo-functionalism advocate the establishment of common institutions with a real mandate. According to the neo-functionalists, stimulus for integration starts from a common interest, and integration should be expanded from a specific field of cooperation into the sectors in which there is interest in mutual cooperation (sectors of interest for regional or sub-regional cooperation, sectors in which cooperation in trans-border areas is possible, etc.). ${ }^{7}$

It could be concluded that within the framework of the theory of functionalism, which is static, functional cooperation is the primary concern, while neofunctionalism is more dynamically oriented and deals with functional integration. Cooperation does not imply common supranational institutions, while integration

\footnotetext{
${ }^{7}$ For further information on the theories of integration and functionalism in this context see: V. Samardžija, European Union and Croatia [Europska unija I Hrvatska] (Zagreb: IMO, 1994); and Radovan Vukadinovic, Theories in International Relations [Teorije o meðunarodnim odnosima] (Zagreb, 1978).
} 
cannot efficiently function without them. According to many indicators, as well as according to historical experience, free movement of labor, goods, services, and capital in South Eastern Europe can only proceed on the basis of functional cooperation. There are many practical as well as political reasons for this. The most important practical reason is the one mentioned above. We are dealing here with countries that are on different levels, not only of economic but also political development. There are, for instance, countries that are nearing their scheduled full membership in the EU (Hungary and Slovenia), which are on a correspondingly higher level of economic development than other countries in the sub-region. Croatia is not only on a much higher level of economic development than the other countries of the SAA and Stability Pact process, but it is also more developed than most of them in terms of both political and economic institutions. Its market is already connected with the European market through many channels, it is a member of the world monetary system, it has organized a national audit, etc. Albania and Macedonia lag behind in this respect, and if the fact is added that in and around those countries the security situation is still unstable, then any cooperation with them carries heightened risks. FR Yugoslavia and Bosnia-Herzegovina are partly protectorates. A national audit, which would be related to the world financial market, does not function there. Thus, it is hard to imagine in this phase how any kind of institutional cooperation, to say nothing about integration, would be established with these states. If you also consider the lower level of development of democratic institutions in these countries - the military and the police, for instance, are not completely de-politicized, the rule of law functions in a very problematic way, etc.- then it is clear that any pressure for any kind of integration within the entire SEE area would be counterproductive and practically unfeasible.

There is another significant reason why any pressure to jump-start the activation of the four freedoms in the region through any kind of integration would be counterproductive. Processes of cooperation between countries, especially those embracing the philosophy of the four freedoms on the basis of liberal internationalism, increasingly develop through non-governmental or non-state actors-that is, through civil society. It is one result of the fact that the international division of labor under the conditions of globalization leads to functional networking, which is the result and the prerequisite of scientific, technical, economic, and political modernization. The participants in such networking are decentralized individuals, who develop cooperation with others on the basis of individual entrepreneurial interests in all kinds of work. It is the very link that connects liberal internationalism on the external level with liberal democracy on the internal level within the framework of every state belonging to that community or aspiring to join it. The free movement of labor, goods, services, and capital in South Eastern Europe should follow that process, which actually means that the adjustment to the conditions of globalization without the eventual alteration of any economic or political process cannot be successful either on the external or the internal level. Emphasis should 
be laid on local protagonists, civil society, and various non-governmental associations, which will develop such functional cooperation in accordance with their authentic interests and will only then have some chance for success, and may even stimulate the process toward higher forms of functional and-when the conditions are created-institutional integration.

The best example of this is economic cooperation, which in order to be successful would have to be initiated from the bottom, i.e., by individual companies, enterprises, associations and entrepreneurs. Regardless of the level of intergovernmental or inter-state cooperation, the businessmen in this region try to cooperate, mutually researching the market, consulting on conditions of payment, etc. ${ }^{8}$ On the basis of the interests of businessmen-the economic segment of civil society-functional cooperation gradually moves to the institutional level by concluding bilateral agreements on free trade (for instance, the agreements between Croatia and all countries of the sub-region). This is an example of moving from functional to institutional cooperation, where the content of this kind of cooperation should be differentiated from the content of possible integration, because now such cooperation is mainly realized on the bilateral level. If raised to the subregional level, it would be a step on the road to integration, but for the time being it is obviously still too early for that. However, with the development of relations at the current level of cooperation, it is possible that, when the conditions are created, this economic subset of civil society in Croatia or some other country of the sub-region, through their associations or even the national chamber of commerce, will compel the establishment of higher forms of functional and even institutional cooperation, and, furthermore, of functional and institutional integration. ${ }^{9}$

In this phase it would be optimal to develop the free movement of labor, goods, services, and capital within the sub-region on the basis of functional cooperation, which, with the development of relations over time, should grow first into institutional cooperation (an example of this are the current bilateral free trade agreements between Croatia and the countries of the sub-region mentioned above), and then, when the conditions warrant, into functional and institutional integration. What this would look like can be illustrated by the example of the development of cooperation in the improvement of mutual trade.

\footnotetext{
${ }^{8}$ A frequently mentioned example for this is the visit of 400 Croatian businessmen to Belgrade immediately after the establishment of the democratic government in Serbia. On the basis of the talks then held, even today business is being concluded without any mediation of the state and regardless of the nature of inter-state relations.

${ }^{9}$ Remember the difference between the contents of cooperation and integration, which is related to the difference between the theories of functionalism and neo-functionalism. Functionalism focuses on cooperation and does not demand the establishment of supranational institutions, while neo-functionalism considers that the process of functional cooperation logically ends with the establishment of supranational institutions as a step towards integration.
} 


\section{Promotion of Mutual Trade}

The promotion of mutual trade must be an important and, based on past experience in Europe and elsewhere, probably the leading component of the broader, long-term economic integration of the countries of SEE as a step toward their integration into EU structures. This long-term vision of regional trade cooperation and eventual integration into the EU contrasts sharply with present reality. Trade relations between the countries of the region are characterized by a variety of restrictions and impediments to trade with each other and with the rest of the world. Moreover, relations with the EU are shaped by a variety of different bilateral trade arrangements that reflect the different states of play of bilateral relations of these countries with the EU. In many conferences and discussions on this issue, the participants have identified numerous concrete actions as priorities for each country, as well as some areas for regional co-operation. The following major themes were common.

Competitiveness is a very important concept for economic and trade development in each country and the region, and it needs to be promoted and used as a basis for further trade development. To increase competitiveness, each country needs to conduct and use competitiveness studies, including cutting-edge methodology; identify and support leaders and clusters of excellence; build a better policy dialogue between business and government; and educate business and government as well as strengthen business associations and promote improved communication and partnerships between business and government. In this context, studies of the country's competitiveness and export potential as grounds for government policy and business strategies are also very important. To this end, training for business and government in areas such as competitiveness, management, marketing, finance, trade, and strategic planning should be provided. The identification of the best regional and international trade and tax policies and practices will provide the framework for the recommendation of policy changes to reduce corruption and unfair competition.

Trade Finance means the development of trade financing and non-banking instruments through the joint work of lenders, business, and government in order to promote export financing and increase access to financing for projects of mutual trade. In this way, a better use of international and regional assistance programs will be encouraged, contacts between lenders and business will be improved, and a better flow of information between lenders and borrowers, especially the improvement of credit information, will be facilitated.

In the field of Administration, enhanced levels of transparency, competence, and efficiency in both governmental and non-governmental administration are needed. Administrative staff must be trained and professionalized, and coordination among and within administrative agencies and economic actors must be improved. 
The Legal Environment must be established in such a way so that the rule of law, which is the basis for the promulgation of existing trade agreements, must be the top priority. The legislative process has to be more transparent, business must be involved in developing legislation, legislative barriers to trade must be identified and reduced, and the currently diverse legal framework must be equalized. Trade law, including international agreements and trade-related laws and regulations, must be published in easily accessible forms and in a user-friendly manner, including on the Internet.

Public and private institutions and organizations must coordinate their efforts to collect and distribute reliable Trade Information; databases, contacts, and trade opportunities should be standardized and audited, and trade shows should be promoted. The coordination and synergy between public and private institutions and organizations in their efforts to collect and distribute reliable trade information should be strengthened. A national database of unified business information, contacts, and trade opportunities should be created by using available sources and ensuring the quality and accuracy of the information. Business associations and governments should promote and assist participation of businesses in trade shows.

All in all, there is a great need for increased cross-border trust and contacts. Information must be improved, standardized, and made readily available. Cooperation between governments is necessary, particularly in standardizing traderelated procedures, laws, and regulations. The establishment of an SEE web site trade navigator, containing tariff and non-tariff trade measures and procedures, with links to international initiatives and national administrations, was proposed, but the idea has not been realized yet.

Regional and bilateral trade shows and conferences would also be very useful, because regional cooperation in competitive regional trade development has to be matched by efficient follow-ups and active cooperation and coordination with different initiatives and donors. Cross-border cooperation and business contacts, especially between SMEs, by promoting free movement of businessmen in the region, supporting regional and bilateral trade events, and improving communication between business support institutions, are also very important. Some kind of gradual cooperation among governments in the region in general and particularly in the areas of taxation, free trade, law enforcement, and coordination of integration into international structures could also be effective tools for enhancing functional cooperation in trade. At the present stage of development, this kind of cooperation can be focused on some kind of exchange of national and regional information about customs procedures and EU and WTO regulations. If this kind of information were widely available in English, it would be of great help. An SEE trade navigator in electronic and paper versions, as mentioned above, could also be a useful tool. 


\section{The Case of Croatia}

We have already mentioned the example of bilateral agreements on free trade, which Croatia concluded with the countries of the sub-region and which are based on functional cooperation, although they already have some characteristics of institutional cooperation (joint committees). Thus, these agreements represent a part of the process that is not only connected to the development of economic relations, but is also influenced by political circumstances. They serve as an example of the problematic nature of inter-state relations in the region and of the complexity of the correlation of economic and political conditions, without whose combined appropriate adjustment no efforts-not even this gesture toward sub-regional cooperation-will accelerate the functioning of the four freedoms in the sub-region. This example also illustrates all the complexity and delicacy of the entire historical and cultural legacy of the whole sub-region, which poses further challenges to the establishment of the four freedoms.

Bosnia-Herzegovina is a particularly important neighbor, with whom Croatian policy will probably have to demonstrate the highest possible degree of diplomatic and political expertise. Although he accepted the Dayton Agreement, President Tudjman at the same time continued to fan the hopes of nationalists in BosniaHerzegovina, thus weakening their desire for cooperation within their own country. The Croatian coalition government made it known from the very beginning that its attitude towards Bosnia-Herzegovina will be different, based on the respect for its state sovereignty and the wish for good relations. The consistent implementation of such a policy has rapidly weakened those Croatian forces in BosniaHerzegovina that opted for secession. The development of normal, bilateral relations and concern for the fate of the Croatian people in Bosnia-Herzegovina has so far enjoyed the strong support of the international community. Under such conditions one can predict intensive economic and political cooperation and the creation of conditions for security along the Croatian border with Bosnia-Herzegovina, which especially gains relevance in the light of the global antiterrorist campaign. This will require the solution of the problem of refugees, both in the Federation and in the Republic of Serbia, and a common approach to cooperation within the Stability Pact based on the following suppositions.

- Cooperation should be focused on the goal of the EU's Eastern enlargement and fit within the framework of the Stabilization and Association Agreement, with the objective being to establish a zone of long-term stability in the region.

- In this regard, close cooperation should be established with the international community as part of its mandate, which is to transform BosniaHerzegovina into a country capable of implementing the main principles and criteria of the European Union. 
- It is of crucial importance for Croatia to intensify cooperation with those Croatian people in Bosnia-Herzegovina who are not responsible for the exodus of Croats from this country, which reduced their numbers by more than half over the past ten years, and which threatens their position as a constituent nation.

- Cooperation between Croatian and Bosniac people in coordination with the international community should be stimulated.

- The international community should have its attention drawn to its excessive tolerance towards the Republic of Serbia, which threatens the integrity of Bosnia-Herzegovina.

- In the economic sphere, functional cooperation should be encouraged, while possible institutional economic cooperation-for instance, in the form of a bilateral free trade zone-will depend on the dynamics of democratization in Bosnia-Herzegovina, on the basis of the Dayton Accords and the Zagreb Summit Declaration.

- Both countries have a specific responsibility to fight illegal immigration, which serves as a perfect channel for terrorists and traffickers going from Central Asia to Europe. Their successful cooperation in controlling very long and, in some spots, inaccessible borders will strengthen their role in the global antiterrorist campaign.

Yugoslavia is Croatia's neighbor with whom it has a number of complex open issues. To start with, Belgrade provided the inspiration and support for the Serb rebellion. The aggression was also spearheaded from that center, and the suffering and destruction as well as the major Serb exodus after the fall of the so-called Krajina sector were also the products of Milosevic's policies. This is fresh history, which cannot be forgotten, although the rational political approach speaks in favor of the beginning of normalization. Croatia needs to be very cautious with every move it makes, because it is still not quite clear whether movements toward "democratic processes" in Yugoslavia are authentic, or whether the new government is simply playing for time to improve the perception of Serbia in the international community (an effort in which it has been partly successful). The international community is still vacillating between the desire to treat "new" Serbia (FR Yugoslavia) as an important guarantor of stability, even at the price of using double standards for it and the other countries in the sub-region, and the need to punish the new authorities for failing to express clearly whether they want to adopt the standards of co-operation, especially co-operation with the International War Crimes Tribunal in The Hague. The international community has not yet defined a clear strategy towards "new" Serbia, opting instead for a wait-and-see policy in 


\section{THE QUARTERLY JOURNAL}

order to give the new authorities more time (especially in view of Serbia's very muted reaction to the terrorist attack on America and their very hesitant supportif that — for the global antiterrorist campaign).

This kind of tolerance towards the so-called democratic authority in Yugoslavia again puts the credibility of the international community seriously at risk. Moreover, with the unresolved question of Kosovo, with Montenegro seeking independence, with Sandyak seeking autonomy, and Vojvodina moving increasingly in the same direction, Yugoslavia is still a source of great uncertainty. The last elections marked just the first step towards greater security in planning bilateral cooperation and concrete moves towards the normalization of relations. Some specific issues (such as the return of refugee Serbs, minimal opening of mutually useful transport routes, and the establishment of the first forms of trade) are possible small steps towards normalization. Everything else will need to wait for a new stage of development in which Yugoslavia, or Serbia, will truly have solved its domestic political issues and started along the path of democratic European development. Only then will it be possible to open up prospects for cooperation on the bilateral and sub-regional levels. The following points need to be made at this stage:

- The main precondition and framework for Croatia's cooperation with Yugoslavia must be the project of EU Eastern enlargement, with the idea of creating a long-term stability zone in the region.

- In this context, cooperation should be adjusted to the dynamics of democratization in Serbia's international relations, which depends mostly on: (a) realistic recognition of the state's responsibility for aggression against three neighboring countries; (b) the quality of its cooperation with the international War Crimes Tribunal in The Hague; (c) the quality of its genuine support for the global antiterrorist campaign; (d) the recognition of the borders of all neighboring countries, especially Bosnia-Herzegovina and Macedonia; (e) the recognition of Montenegro's right to independence.

- Once positive developments are recorded in these domains, a high degree of formal and institutional relations should be established within a broader regional and security regime.

- The international community should be informed repeatedly that the geopolitical situation in this part of the world has changed so much that Serbia can no longer be the main guarantor of sub-regional stability, and that any insistence on such a perception slows down and threatens the establishment of the security zone in the region. The best evidence for this is Yugoslavia's hesitating support for the global antiterrorist campaign. 
- In the economic domain, functional economic cooperation should be encouraged at this stage, and any institutional cooperation-for instance, the unrealistic idea of a regional customs union—should be rejected.

- If political developments in Montenegro should come out in favor of independence, Croatia should immediately recognize that country as an independent international legal entity.

Slovenia and Croatia emerged from Yugoslavia together, but their paths soon parted. While Slovenia continued to systematically build its European political, economic, and cultural structure, Croatia remained buried under its domestic difficulties and problems. The issues marring their bilateral relations (Bay of Piran, the Ljubljanska Banka debt, the Krsko nuclear power plant) should not have posed major difficulties for normalization. But since the two countries were new states that wanted to demonstrate their sovereignty at all costs, together they created conditions that aggravate the problem and block cooperation. The new approach by Croatia - and, one hopes, also by Slovenia - should lead to a relatively quick solution of all the disputes, allowing the many elements that bind them to take precedence. Croatia is an appealing economic market for Slovenia, while the Adriatic coast is a traditional destination for Slovene tourists. For Croatia, Europe begins on the border with Slovenia, and through Slovenia Croatia can reach Europe much faster, both economically and politically. The two countries also share the same view on cooperation in South Eastern Europe, the question of succession, and Slovenia's help to Croatia in joining CEFTA. Given political goodwill, it is possible to predict many new developments in the interest of both countries that might also promote Croatia's image abroad.

Hungary is the neighbor with whom Croatia has developed the best relations, unburdened by any open issues. To this we should also add the expressed readiness of Hungary to continue to cooperate in the same spirit; the Croatian authorities should continue to build relations that will establish deeper ties between the two neighboring Danubian countries. Hungary is moving quickly towards full membership in the European Union. It is a NATO member already, and is also a participant in the Stability Pact. Croatia could draw many valuable lessons from studying the Hungarian progress towards integration in Euro-Atlantic organizations, and the Hungarian vote of support might be very important as Croatia bids to join CEFTA and later the EU.

\section{Conclusion}

This paper deals with the possibility of the establishment of the four freedoms in the SEE sub-region, which is considered here in a wider sense than the part of the region covered by the Stability Pact and the SAA process. The progress of the four freedoms cannot be restricted either institutionally or politically, starting 


\section{THE QUARTERLY JOURNAL}

from the assumption that all countries that participate in the community defined by these freedoms share the same value system. The question at hand is the model of liberal internationalism in foreign relations and the model of liberal democracy in internal relations. The EU is also established on that model, as are all the phases of its enlargement including the most recent, Eastern phase.

Thus, all countries that want to become members of the European Union must gradually secure the functioning of the four freedoms, not only vis-à-vis current EU members, but also with respect to new members, and particularly their neighbors in South Eastern Europe. This applies to all nations in the SEE sub-region, although due to the historical and cultural heritage in the area, whose effects burden even the most recent past, it will not be so simple. This is also true for some other areas and sub-regions. A mechanical or bureaucratic comparison with the examples of other sub-regions would be counterproductive in the SEE area. Since sub-regional cooperation based on the philosophy of the four freedoms is in the direct national interest of all countries in the sub-region, and is also in the wider regional interest, especially in terms of security, it should be approached carefully, taking into account the specific characteristics of the area with an optimal combination of respecting narrower national but also wider regional and sub-regional interests. On the basis of both the theory and the practice of international cooperation and integration, functional cooperation between the countries in this phase seems to be an appropriate step toward satisfying all those interests. In accordance with the democratization of internal relations of all countries in the sub-region, this cooperation would gradually grow into functional integration, and then into institutional cooperation and integration. The EU for its part will facilitate and speed up this process if it offers these countries a clear and credible prospect of rapid entrance into the Union.

Non-governmental organizations and associations-the institutions of civil society of all the countries under discussion — can play a significant role in this process. They can become main protagonists of the functional linkage between states and can gradually encourage the entire process leading toward the goal of EU membership. The exchange of information, publications, experts, the organizing of scientific and expert conferences in various fields of cooperation, the elaboration of joint projects - all this can have an impact on the increase of knowledge and interest in cooperation, which then, depending on other political and security circumstances, can more rapidly accomplish all the phases from functional to institutional cooperation and integration.

As for Croatia, due to its geographic position at the center of this strategically important project, the Stability Pact (although only under the previously mentioned preconditions) opens new possibilities for its internal economic development, since it will be released from the need to continue allocating a significant part of its GDP to defense and security. The Stability Pact also provides a good basis for Croatia's faster involvement in European and global security structures. 
No.2, June 03

\section{Further Reading}

Bornschier, Chase-Dunn. The Future of Global Conflict. London: Sage Publications, 1998.

Frieden, Jeffrey A., and David Lake. International Political Economy. New York: St. Martin's Press, 1995.

Nikic, G., V. Samardžija, and M. Stanicic. Koristi i troskovi ulaska Hrvatske u EU. Zagreb: IMO, 2000.

Rosati, Dariusz. Economic Disparities in Central and Eastern Europe and the Impact of EU Enlargement. Geneva: UNECE, 1998.

Stanicic, Mladen. “Editorial," Croatian International Relations Review 17 - 19. Zagreb: IMO, 1999. 


\section{Bibliography}

Meyers, Reinhard. Temeljni pojmovi i teorijske perspektive meðunarodnih odnosa . Osijek- Zagreb-Split: Pan-Liber, 1999.

Samard ija, V.. European Union and Croatia [Europska unija I Hrvatska]. Zagreb: IMO, 1994.

Vukadinovic, Radovan. Security in the southeast of Europe [Sigurnost na jugoistoku Europe]. Zagreb: HUMS, 1999.

Vukadinovic, Radovan. Theories in International Relations [Teorije o meðunarodnim odnosima]. Zagreb, 1978. 